JUSTYNA MISIĄGIEWICZ

Instytut Nauk o Polityce i Administracji

Wydział Politologii i Dziennikarstwa

Uniwersytet Marii CURIE-Skłodowskiej w Lublinie

ORCID: 0000-0003-0224-2735

justyna.misiagiewicz@poczta.umcs.lublin.pl

\title{
Polityka bezpieczeństwa energetycznego Azerbejdżanu w regionie kaspijskim
}

\section{Azerbaijan's energy security policy in the Caspian region}

Słowa kluczowe:

Azerbejdżan, polityka bezpieczeństwa energetycznego, region kaspijski
Keywords:

Azerbaijan, energy security policy, Caspian region 


\section{Azerbaijan's energy security policy in the Caspian region}

In contemporary international relations, the energy security is becoming a key issue. Access to energy resources is the existential need of every state, conditioning its economic and social development. Interdependencies in the energy field are a key determinants of international relations, where the participants are not only states but also non-sovereign actors. The research problem of the study is the analysis of Azerbaijan's energy security policy priorities in the Caspian region. The main aim of the research is to present its interests, conditions and activities in the energy security policy dimension. Pipeline geopolitics and security threats influence the strategic goals of Azerbaijan's policy, a pioneer in the development of the energy sector in the Caspian region. 


\section{Uwagi wstępne}

Dolityka bezpieczeństwa energetycznego zakłada dążenie do ochrony państwa i społeczeństwa przed licznymi zagrożeniami, których mnogość, nieprzewidywalność i złożoność wynikają z poliarchicznego środowiska międzynarodowego. Zagrożenia bezpieczeństwa energetycznego są dynamiczne, zmienne i podlegają ewolucji. W takiej sytuacji państwa starają się konstruować długoterminowe polityki bezpieczeństwa energetycznego, mające zapewnić płynne dostawy surowców, zdywersyfikować drogi eksportu i czerpać jak największe zyski ze sprzedaży nośników energiii.

Problemem badawczym jest $\mathrm{w}$ tym kontekście analiza dynamiki polityki bezpieczeństwa energetycznego Azerbejdżanu w specyficznej geoenergetycznej i geostrategicznej przestrzeni regionu kaspijskiego z uwzględnieniem zmienności jego środowiska bezpieczeństwa. Wyzwaniem dla polityki bezpieczeństwa energetycznego tego państwa jest tym samym niestabilność regionu kaspijskiego oraz zwiększająca się rywalizacja między różnymi aktorami, suwerennymi i niesuwerennymi w wymiarze politycznym i gospodarczym, w kontekście budowy newralgicznej infrastruktury energetycznej ${ }^{1}$. Interesy Azerbejdżanu w regionie kaspijskim warunkowała więc geopolityczna rywalizacja dotycząca dróg eksportu surowców, strategiczne usytuowanie między Europą i Azją Centralną oraz specyfika procesu budowania państwa w oparciu o zasoby surowcowe ${ }^{2}$.

Głównym celem poznawczym badań jest przedstawienie interesów, uwarunkowań oraz działań tego państwa $\mathrm{w}$ wymiarze polityki bezpieczeństwa energetycznego. W opracowaniu weryfikacji poddano hipotezę badawczą, mówiącą, iż specyfika polityki bezpieczeństwa energetycznego Azerbejdżanu jest warunkowana jego pozycją geopolityczną, potencjałem surowcowym oraz ewolucją środowiska bezpieczeństwa w regionie kaspijskim. Metoda czynnikowa była przydatna w celu identyfikacji, klasyfikacji i hierarchizacji uwarunkowań polityki bezpieczeństwa energetycznego Azerbejdżanu w regionie kaspijskim, co umożliwiło realizację założonego problemu badawczego.

1 P. Ipek, Azerbaijan's foreign policy and challenges for energy security, "Middle East Journal" 2009, vol. 63, issue 2, ss. 228-239.

2 Tamże, ss. 228-239. 


\section{Koncepcja polityki bezpieczeństwa energetycznego Azerbejdżanu}

Potencjał energetyczny stał się narzędziem realizacji podstawowych interesów strategicznych Azerbejdżanu oraz podstawą jego działań w stosunkach międzynarodowych. W tym kontekście długoterminową strategią Azerbejdżanu od lat 90. było przyciąganie inwestycji zagranicznych w branży energetycznej, co miało wzmocnić bezpieczeństwo państwa zwłaszcza w wymiarze gospodarczym.

Obecnie ramy strategiczne polityki bezpieczeństwa energetycznego Azerbejdżanu obejmują następujące dokumenty: Koncepcja rozwoju „Azerbejdżan 2020: spojrzenie w przyszłość", przyjęta dekretem prezydenckim nr 800 z dnia 22 grudnia 2012 roku oraz 12 strategicznych map drogowych (SRM) zatwierdzonych dekretem prezydenckim nr $1138 \mathrm{z}$ dnia 6 grudnia $2016 \mathrm{roku}^{3}$. Koncepcja rozwoju wyznacza główne cele strategiczne dla polityki państwa w wymiarze gospodarczym. W odniesieniu do sektora energetycznego dokument zawiera deklarowany cel dostosowania ilości energii zużywanej do wytworzenia jednej jednostki PKB oraz wielkości emisji dwutlenku węgla w Azerbejdżanie do odpowiednich wskaźników państw OECD. Dokument wyznacza również priorytety w zakresie zrównoważonej energii, są to: modernizacja sektora naftowo-gazowego i petrochemicznego, szersze wykorzystanie energii alternatywnej i odnawialnej oraz zastosowanie środków efektywności energetycznej. Jednocześnie cele związane z energią nie są ani konkretne, ani mierzalne, co bardzo utrudnia monitorowanie i ocenę postępów w ich realizacji ${ }^{4}$.

Strategiczne mapy drogowe (SRM) to najnowszy zestaw dokumentów strategicznych. Główna SRM nosi nazwę: „Strategiczna Mapa Drogowa Perspektyw Gospodarki Narodowej" ${ }^{\prime \prime}$. Strategia, cele i plany działania związane $\mathrm{z}$ energią są przedstawione $\mathrm{w}$ trzech głównych dokumentach: SRM w sprawie perspektyw gospodarki narodowej; SRM w sprawie rozwoju prze-

3 In-depth review of the energy efficiency policy of the Republic of Azerbaijan. Energy Charter Protocol on Energy Efficiency and Related Environmental Aspects, International Energy Charter, 2019, s. 83: <https://www.energycharter.org/what-we-do/energy-efficiency/energy-efficiency-country-reviews/in-depth-review-of-energy-efficiency-policies-and-programmes/in-depth-review-of-the-energy-efficiency-policy-of-the-republic-of-azerbaijan/> [dostęp: 12 IX 2021].

4 Tamże, s. 84.

5 Tamże, s. 84 . 
mysłu naftowego i gazowego; SRM w sprawie rozwoju użyteczności publicznej (w tym energii elektrycznej, ciepła, gazu i wody). SRM w sprawie perspektyw gospodarki narodowej obejmuje strategiczne kierunki polityki energetycznej na okres po 2025 roku: „kontynuując eksploatację swoich bogatych zasobów naturalnych, Azerbejdżan będzie zwracał większą uwagę na ochronę środowiska i redukcję emisji dwutlenku węgla"6. SRM w sprawie rozwoju przemysłu naftowego i gazowego jest dokumentem zastrzeżonym, a główne cele strategiczne dla tego sektora nie są publicznie dostępne.

Oprócz dokumentów strategicznych w lipcu 2015 roku Minister Energii zatwierdził „10 Zadań Strategicznych” mających na celu wprowadzenie reform rynkowych $\mathrm{w}$ Azerbejdżanie, w tym: przygotowanie strategii rozwoju sektora energetycznego na następne 25-30 lat; opracowanie 15-20-letniego programu państwowego na rzecz efektywnego wykorzystania zasobów energetycznych, poprawy efektywności energetycznej odbiorców końcowych oraz wykorzystania alternatywnych źródeł energii. Należy również zauważyć, że dokument nie określa ram czasowych realizacji tych zadañ ${ }^{7}$. Mimo iż strategiczny wymiar polityki bezpieczeństwa energetycznego Azerbejdżanu uwzglęldnia kwestie ochrony klimatu czy zwiększenie eksploatacji źródeł odnawialnych, nie znajduje to odzwierciedlenia ani w miksie energetycznym tego państwa, ani w polityce produkcji surowców energetycznych.

W deklaracjach liderów politycznych z lat 90., jak i obecnie pojawia się kwestia bezpieczeństwa energetycznego. Przytaczając słowa Vəfa Mirzağa oğlu Quluzadə Vafa, doradcy do spraw polityki zagranicznej prezydenta Heydəra əliyeva, „ropa, to nasza strategia, to nasza obrona i nasza niepodległość"s. Kwestię tę rozwinął prezes Państwowego Przedsiębiorstwa Naftowego Republiki Azerbejdżanu (State Oil Company of the Azerbaijan Republic - socAR), Sabit Aydın oğlu Bağırov, deklarując, iż ,jedynym sposobem na nawiązanie stosunków gospodarczych i politycznych Azerbejdżanu z Zachodem, jest ropa naftowa oraz udostępnienie Zachodowi terytorium Azerbejdżanu jako nowej strategicznej drogi do Azji Centralnej”’

6 Tamże, s. 84 .

7 Tamże, s. 85 .

8 J.Goldberg, Getting crude in Baku. The crude face of global capitalism, "The New York Times Magazine" [online], 4 X 1998 [dostęp: 12 V 2019]: <https://www.nytimes.com/1998/10/o4/magazine/the-crude-face-of-global-capitalism.html $\rangle$.

9 S. Bagirov, Azerbaijan's strategic choice in the caspian region, [w:] The security of the Caspian Sea region, ed. G. Chufrin, Oxford University Press, London 2001, ss. 179-180. 
Zgodnie z deklaracją prezydenta İlhama Jliyeva, „bezpieczeństwa energetycznego nie można rozpatrywać $\mathrm{w}$ oderwaniu od bezpieczeństwa narodowego ${ }^{\prime 10}$. Podczas orędzia noworocznego w 2007 roku prezydent podkreślił znaczenie kwestii związanych $\mathrm{z}$ rozwojem infrastruktury energetycznej, a w szczególności rurociągów i eksploatacji zasobów w regionie pól gazowych Şahdəniz. Stwierdził on, iż „te historyczne fakty determinują długoterminową strategię rozwoju Azerbejdżanu, wzmocnią gospodarkę i pozycję międzynarodową tego państwa"11. Prezydent zwrócił również uwagę na to, iż zacieśnienie współpracy z Zachodem może doprowadzić do zaostrzenia stosunków z Rosją, zwłaszcza w sytuacji, kiedy Azerbejdżan stał się poważnym graczem i wyzwaniem dla pozycji tego mocarstwa w regionie Kaukazu $^{12}$. Azerbejdżan obawiał się agresywnych działań Rosji na obszarze posowieckim ${ }^{13}$. Mając na uwadze doświadczenie Ukrainy, nie chciał być postrzegany jako kluczowy sojusznik Unii Europejskiej w jej planach osłabiania pozycji Rosji na rynku gazowym. Istniało również ryzyko destabilizacji sytuacji w Azerbejdżanie po zakończeniu konfliktu w Górskim Karabachu. Tym samym ważnym elementem strategii bezpieczeństwa energetycznego tego państwa stała się konieczność prowadzenia zrównoważonej polityki zarówno wobec Rosji, jak i UE.

Zgodnie z Koncepcją Bezpieczeństwa Narodowego Republiki Azerbejdżanu integracja ze strukturami europejskimi to jeden z priorytetów polityki państwa ${ }^{14}$. W lipcu 2015 roku prezydent İlham Jliyev zadeklarował, iż Azerbejdżan nie dąży do pełnego członkostwa w Unii Europejskiej, ale do strategicznego partnerstwa $\mathrm{z}$ jej strukturami. Podstawą relacji UE

10 Ilham Aliyev: Energy security cannot be considered apart from national security, AEA Albania Energy Asociation [online], 18 XI 2015 [dostęp: 12 IX 2021]: <https://aea-al.org/ ilham-aliyev-energy-security-cannot-be-considered-apart-from-national-security/ $\rangle$.

11 I. Aliyev, Azeri leader sets key priorities for 2007, “BBC Monitoring Trans Caucasus Unit", 1 I 2007.

12 A. Cohen, Energy security in the Caspian basin, [w:] Energy security challenges for 21st century, eds G. Luft, A. Korin, Greenwood Publishing Group, Santa Barbara 2009, s. 122.

13 Zob.: J. Misiągiewicz, The Caspian states perception of the conflict between the Ukraine and Russia, [w:] Neighbourhood perceptions of the Ukraine Crisis, eds K. Stokłosa, G. Besier, Routledge, London - New York 2017.

14 Republic of Azerbaijan, National Security Concept of the Republic of Azerbaijan, 2007, ss. 8-9: http://www.azembassy.org.au/uploads/docs/Azerbaijan.pdf> [dostęp: $29 \times 2015]$. 
i Azerbejdżanu jest jednak kwestia produkcji i transportu surowców energetycznych oraz realizacja wspólnych projektów gazowych ${ }^{15}$.

W listopadzie 2019 roku prezydent İlham Jliyev oświadczył, że Azerbejdżan nie jest zainteresowany udziałem w inicjatywie Partnerstwa Wschodniego. Stosunki tego państwa z Unią ulegały również stopniowemu pogorszeniu między innymi w wyniku kryzysu w relacjach tej struktury z Turcją, interpretowanego jako działania antymuzułmańskie ${ }^{16}$. W stosunkach z UE priorytetem Azerbejdżanu jest jednak współpraca w wymiarze ekonomicznym ${ }^{17}$. Państwa członkowskie są bowiem największym partnerem handlowym i odbiorcą azerskich surowców (ok. 55\% wymiany handlowej) oraz źródłem bezpośrednich inwestycji ${ }^{18}$.

Azerbejdżan dąży do umocnienia swojej niezależności i rozwoju gospodarczego w kontekście rywalizacji geopolitycznej, wynikającej z różnorodności interesów podmiotów państwowych i niepaństwowych, zaangażowanych w budowę dróg eksportowych dla ropy i gazu w regionie kaspijskim ${ }^{19}$.

\section{Uwarunkowania polityki bezpieczeństwa energetycznego Azerbejdżanu w regionie kaspijskim}

\section{Pozycja geopolityczna Azerbejdżanu}

Region kaspijski stanowi centrum gry geopolitycznej i geoekonomicznej jako pomost między Bliskim Wschodem, byłymi republikami radzieckimi oraz strefą euroatlantycką. Można śmiało stwierdzić, iż z uwagi na usytuowanie w centrum Eurazji staje się on coraz bardziej znaczący w wymiarze globalnych relacji międzynarodowych. Według Halforda Mackindera obszar ten jest częścią eurazjatyckiego Heartlandu ${ }^{20}$. Tym samym jego

15 A. Jarosiewicz, Południowy Korytarz Gazowy. Azersko-turecki projekt w rozgrywce Rosji i UE, Ośrodek Studiów Wschodnich, Warszawa 2015 (Punkt Widzenia, 54), s. 28; V. Pop, EU too divided to solve frozen conflicts, Azerbaijan says, "EU Observer" [online], 9 X 2008, [dostęp:15 X 2015]: 〈https://euobserver.com/energy/26894〉.

16 A. Legieć, Perspektywy polityki wewnętrznej i zagranicznej Azerbejdżanu, Polski Instytut Spraw Międzynarodowych, Warszawa 2020 (Biuletyn PISM, 87), ss. 1-2.

17 E. van Gils, Azerbaijan and the European Union, Routledge, New York 2020.

18 A. Legieć, Perspektywy polityki wewnętrznej i zagranicznej Azerbejdżanu..., ss. 1-2.

19 P. Ipek, Azerbaijan's foreign policy..., ss. 228 - 239.

20 S. Dalby, American security discourse: the persistence of geopolitics, "Political Geography Quarterly" 1990, issue 9(2), ss. 171-188. 
kontrola stanowi podstawę dominacji w całej Eurazji, a w konsekwencji w całym świecie.

Prawdopodobnie to Napoleon stwierdził, że „jeśli zna się położenie geograficzne państwa, zna się również jego politykę zagraniczną"21. Azerbejdżan, mimo iż jest to państwo o niewielkich rozmiarach i liczbie ludności, ma duże znaczenie geopolityczne. Zbigniew Brzeziński określił je, jako „korek od butelki kryjącej bogactwa państw basenu Morza Kaspijskiego i Azji Środkowej" ${ }^{\prime 22}$. Tożsamość geopolityczna warunkuje więc strategię bezpieczeństwa energetycznego Azerbejdżanu jako kluczowego gracza w regionie kaspijskiego ${ }^{23}$. Jest to państwo poradzieckie. Wspólnota Niepodległych Państw to ważny punkt odniesienia w tym kontekście. Historycznie warunkowane relacje Azerbejdżanu z państwami WNP stanowią bowiem zjawisko niejako naturalne. Jednocześnie jest to państwo muzułmańskie i członek Organizacji Współpracy Państw Islamskich ${ }^{24}$. Azerbejdżan posiada silne więzy kulturowe z Turcją. Przejawem tego jest jego uczestnictwo w Radzie Współpracy Państw Tureckojęzycznych ${ }^{25}$.

Oprócz tego wymiar geopolityczny pozycji Azerbejdżanu wynika z faktu, iż jest to państwo europejskie oraz że współpraca ze strukturami zachodnimi to priorytet jego polityki zagranicznej. Azerbejdżan jest członkiem Zgromadzenia Parlamentarnego Rady Europy oraz utrzymuje bliskie relacje z państwami i instytucjami $\mathrm{UE}^{26}$. Operacja NATO w Afganistanie była również platformą pogłębienia współpracy z Azerbejdżanem w ramach struktury Partnerstwa dla Pokoju ${ }^{27}$. W styczniu 2014 roku Azerbejdżan lenges and prospects, "Valdai Discussion Club" [online] 2017: <http://valdaiclub.com/ files/13184/> [dostęp: 15 VI 2017].

24 P. Goble, Azerbaijan's balanced foreign policy and the Muslim world, "Azerbaijan in the World" 2009, issue 2(12), ss. 3.

25 F. Mammadov, Foreign policy postures and priorities of Azerbaijan, [w:] The South Caucasus - security, energy and europeanization, eds M. B. Altunisik, O. F. Tanrisever, Routledge, London - New York 2018, ss. 85-100.

26 Tamże, ss. 85-100.

27 Joint press point with NATO Secretary General Anders Fogh Rasmussen and the President of Azerbaijan, Ilham Heydar oglu Aliyev, NATO [online], 15 I 2014 [dostęp: 27 IX 2015]: 〈http://www.nato.int/cps/en/natolive/opinions_106145.htm?selectedLocale=en >. 
zaangażował się we współpracę z NATO w ramach Response Force (NRF) i Resolute Support. W 2016 roku prezydent İlham Jliyev odwiedził kwaterę NATO oraz uczestniczył w szczycie w Warszawie. Zadeklarował, iż „uczestnictwo w misjach pokojowych NATo to kluczowa część naszej współpracy"28. Współpraca Azerbejdżanu i państw NATO dotyczy w szczególności ochrony energetycznej infrastruktury krytycznej.

Azerbejdżan, usytuowany na przecięciu wschodu i zachodu, północy i południa Eurazji, stanowi kluczowe państwo w wymiarze transportowym. Zainicjował i aktywnie uczestniczył w strategicznych transregionalnych projektach transportowych, takich jak połączenie kolejowe Baku - Tbilisi - Kars czy Międzynarodowy Morski Port Handlowy w Baku. Międzynarodowy Port w Baku stanowi główny hub handlowy i logistyczny w regionie, będąc elementem projektu Transport Corridor Europe - Caucasus - Central Asia (TRACECA) łączącego Azję i Europę w wymiarze handlowym ${ }^{29}$. Oprócz tego Azerbejdżan, Kazachstan i Gruzja są zainteresowane poszerzeniem możliwości transportu towarowego poprzez Trans-Caspian International Transport Route oraz zgodziły się na utworzenie w kwietniu 2016 roku Trans-Kaspijskiego Międzynarodowego Konsorcjum Transportowego ${ }^{30}$.

W związku z korzystną pozycją geostrategiczną Azerbejdżan odğrywa rolę tranzytową, przez jego terytorium przebiega najkrótsza droga łącząca Europę z Azją. W sierpniu 2016 roku odbył się szczyt Azerbejdżanu, Rosji i Iranu w Baku, którego celem było wdrożenie projektu North-South Transport Corridor ${ }^{31}$. Azerbejdżan stanowi również kluczowy element połączeń teleinformatycznych $\mathrm{w}$ regionie, w ramach projektu Eurasian Information Super Highway (TASIM), który ułatwia współpracę regionalną $\mathrm{w}$ wymiarze infrastruktury $\mathrm{ICT}^{32}$.

28 NATO in the Caucasus. The case of Azerbaijan, 2014 [dostęp: 19 IX 2015]: <http://www. isn.ethz.ch/Digital-Library/Audio/Detail/?lng=en\&id=183160 >.

29 E. Jafarova, The role of Azerbaijan in shaping regional cooperation for energy security, [w:] Addressing emerging security risks for energy networks in South Caucasus, eds J. Novogrockiene, E. Siaulyte, IOS Press, Amsterdam 2017, ss. 41-44.

30 Tamże, ss. 41-44.

31 Tamże, ss. 41-44.

32 Tamże, ss. 41-44. 
Azerbejdżan odgrywa więc znaczącą rolę geopolityczną w środowisku międzynarodowym. Polityka tego państwa posiada cechy wielowektorowości i oparta jest o zasadę równowagi w stosunkach międzynarodowych ${ }^{33}$.

\section{Zasoby surowcowe Azerbejdżanu}

Potencjał surowcowy Azerbejdżanu w sposób zasadniczy warunkuje jego politykę bezpieczeństwa energetycznego. Państwo to było pionierem rozwoju sektora energetycznego w regionie kaspijskim i w skali globalnej ${ }^{34}$. Powstała tu pierwsza na świecie rafineria, pole naftowe i platforma wiertnicza. Główne zasoby ropy w tym państwie ulokowane są na Półwyspie Apszerońskim, niedaleko Baku. Ich odkrycie rozpoczęło długą historię sektora naftowego w regionie kaspijskim. W 1846 roku odnotowano tu pierwsze oficjalne wydobycie ropy na świecie ${ }^{35}$. Produkcja ropy na skalę przemysłową rozpoczęła się w 1847 roku na polach Ramany, Balakhany, Sabunchu, i Bibi-Heybat. Przytaczając za szefem SOCAR, Rovnag Ibrahim oglu Abdullayevem, Azerbejdżan był pierwszym państwem eksploatującym złoża przybrzeżne i morskie ropy oraz pierwszym, które używało tankowców do transportu ropy ${ }^{36}$.

Region Baku od XIX wieku stanowił jedną z najbogatszych w surowce energetyczne prowincji na świecie. Wydobywano tu wtedy około połowy światowych zasobów ropy ${ }^{37}$. Ten imponujący poziom produkcji wynikał z inwestycji braci Roberta, Ludwiga i Alfreda Noblów oraz firmy Royal Dutch Shell. W latach 6o. XIX wieku, Azerbejdżan zaczął rywalizować z USA w kwestii rozwoju wiedzy inżynieryjnej i nowych technologii w branży naftowej. W tym okresie coraz większą rolę odgrywały inwestycje zagraniczne

33 J. Strakes, Azerbaijan and the Non-Aligned Movement: Institutionalizing the 'Balanced Foreign Policy' Doctrine, "IAI Working Papers" 2015, no. 11, ss. 5-8.

34 Od czasów starożytnych Azerbejdżan był znany z faktu posiadania zasobów surowcowych. Mieszkańcy tego obszaru obawiali się łatwopalnego gazu wydobywającego się spod powierzchni ziemi, a Azerbejdżan nazywano „ziemią ognia”. R. Huseynzade, A. Aliyev, Experience of Azerbaijan in construction of main oil and gas pipelines in the Caspian Sea Region. Environmental aspects, [w:] Oil and gas pipelines in the Black-Caspian Seas Region, eds I.S.Zonn, A. G. Kostianoy, Springer, Switzerland 2016, ss. 169-196.

35 Tamże, ss. 169-196.

36 E. Svyatets, Energy security and cooperation in Eurasia. Power, profits and politics, Routledge, New York 2016, ss. 74-109.

37 G. Bahgat, Energy security. The Caspian Sea, "Minerals \& Energy" 2005, vol. 20, issue 2, s. 6. 
$\mathrm{w}$ tym sektorze. Pierwszy tankowiec został zbudowany w Baku przez Ludwiga Nobla pod koniec XIX wieku ${ }^{38}$. Produkcja ropy w Azerbejdżanie przyciągała zagranicznych inwestorów i była kontrolowana przez potężnych przedsiębiorców: braci Nobel i Rothschild oraz Taghiyeva, Naghiyeva, Mukhtarova i Hajinskyego ${ }^{39}$.

Ropa kaspijska stanowiła wartość strategiczną podczas obu wojen światowych. Za każdym razem Niemcy próbowali bezskutecznie opanować $\mathrm{Baku}^{40}$. Pola naftowe Azerbejdżanu były głównym źródłem zaopatrzenia w ropę Związku Radzieckiego podczas II wojny światowej ${ }^{41}$. W latach 50. XX w., po tym, jak odkryto zasoby ropy na Uralu i Syberii, Rosja przeniosła swoje inwestycje energetyczne z regionu kaspijskiego. Zmniejszyło to wydobycie na tym obszarze.

Po rozpadzie ZSRR Azerbejdżan zaczął prowadzić niezależną politykę energetyczną ${ }^{42}$. Przemysł energetyczny tego państwa rozwinął się w latach 90. XX w. i na początku XXI w. Siła gospodarcza Azerbejdżanu opiera się $\mathrm{w}$ dużej mierze na dochodach $\mathrm{z}$ handlu ropą ${ }^{43}$. Jest to bowiem kluczowy producent surowców węglowodorowych na obszarze posowieckim (tabela 1, 2). Wielość dostępnych źródeł statystycznych utrudnia ujednolicenie danych dotyczących produkcji ropy naftowej przez Azerbejdżan. Według danych SOCAR po osiągnięciu szczytu produkcji w latach 20092010, w latach 2011 i 2012 poziom produkcji w tym państwie znacząco spadł i wyniósł $43,5 \mathrm{mln}$ ton rocznie ${ }^{44}$. Obecnie, wg BP Statistical Review of World

38 D. Yergin, The quest. Energy, security, and the remaking of the modern world, Penguin Books, New York 2011, s. 50.

39 E. Svyatets, Energy Security ..., ss. 74-109.

40 G. Bahgat, Central Asia and energy security, „Asian Affairs” 2006, vol. 37, issue 1, s. 3.

41 M. Terterov, The energy charter as a framework for intergovernmental cooperation in the energy markets of the South Caucasus states, [w:] The South Caucasus - security..., ss. 213-230; US Energy Information Administration [online], [dostęp: 10 II 2015]: 〈http://www.eia.gov/beta/international/?fips=aj $>$.

42 Zob.: S. Kolundzić, Eurasia, enerǵy cooperation or conflict?, part 2.: Caspian Region, oil and geopolitics, "NAFTA" 2009, vol. 4, issue 60, ss. 203-212.

43 M. Terterov, The energy charter ..., ss. 213-230.

44 K. Kosowska, R. Czarnota, J. Stopa, P. Wojnarowski, D. Janiga, Azerbaijan facing new challenges on the energy market after the collapse of Soviet Union, [w:] Section Oil and Gas Exploration, 18 International Multidisciplinary Scientific GeoConference SGEM 2018, ss. 267-274. 
Energy z 2021 roku, Azerbejdżan produkuje 716 tys. baryłek dziennie, co stanowi o,8\% udziału w skali globalnej ${ }^{45}$.

Tabela 1. Produkcja ropy naftowej w Azerbejdżanie w latach 2001-2020 (baryłek dziennie)

\begin{tabular}{|c|c|c|c|c|c|}
\hline $\mathbf{2 0 0 1}$ & $\mathbf{2 0 0 4}$ & $\mathbf{2 0 0 5}$ & $\mathbf{2 0 0 8}$ & $\mathbf{2 0 0 9}$ & $\mathbf{2 0 1 0}$ \\
\hline 307,200 & 312,800 & 477,00 & $1,099,000$ & $1,011,000$ & $1,041,000$ \\
\hline $\mathbf{2 0 1 1}$ & $\mathbf{2 0 1 2}$ & $\mathbf{2 0 1 6}$ & $\mathbf{2 0 1 8}$ & $\mathbf{2 0 2 0}$ & \\
987,000 & 931,9000 & 842,000 & 789,300 & 798,000 & \\
\hline
\end{tabular}

Źródło: Index Mundi: <https://www.indexmundi.com/g/g.aspx?v=88\&c=aj\&l=en> [dostęp: 25 VIII 2020].

Po Rosji i Kazachstanie Azerbejdżan posiada największe zasoby ropy i gazu w regionie. Zgodnie $\mathrm{z}$ danymi przytaczanego BP Statistical Review of World Energy z 2021 roku, udokumentowane zasoby ropy w tym państwie wynoszą 7 mld baryłek (1 mld ton), co stanowi o,4\% rezerw światowych, oraz 2,5 tryliona $\mathrm{m}^{3}$ gazu, stanowiących $1,3 \%$ rezerw światowych ${ }^{46}$. Szacowane rezerwy ropy w przypadku tego państwa, to około 10 mld baryłek. Natomiast szacowane rezerwy gazu to około 3 trylionów $\mathrm{m}^{3}$.

Tabela 2. Produkcja gazu ziemnego w Azerbejdżanie w latach $2001-2020\left(\mathrm{~m}^{3}\right)$

\begin{tabular}{c|c|c|c|c|c|}
$\mathbf{2 0 0 1}$ & $\mathbf{2 0 0 3}$ & $\mathbf{2 0 0 4}$ & $\mathbf{2 0 0 7}$ & $\mathbf{2 0 0 9}$ & $\mathbf{2 0 1 0}$ \\
$\mathbf{5 , 7 2 0 , 0 0 0 , 0 0 0}$ & $5,130,000,000$ & $5,010,000,000$ & $9,770,000,000$ & $16,520,000,000$ & $16,680,000,000$ \\
\hline $\mathbf{2 0 1 1}$ & $\mathbf{2 0 1 3}$ & $\mathbf{2 0 1 6}$ & $\mathbf{2 0 1 8}$ & $\mathbf{2 0 2 0}$ & \\
$17,860,000,000$ & $18,200,000,000$ & $29,370,000,000$ & $16,960,000,000$ & $16,960,000,000$ &
\end{tabular}

Źródło: Index Mundi :<https://www.indexmundi.com/g/g.aspx?v=136\&c=aj\&l=en> [dostęp: 25 VIII 2020].

Również w wymiarze konsumpcji surowców energetycznych ropa i gaz to główne elementy miksu energetycznego tego państwa (diagram 1). Gaz stanowi ponad dwie trzecie konsumpcji energii w tym państwie, a ropa prawie jedną trzecią. W ostatniej dekadzie konsumpcja produktów ropopochodnych w Azerbejdżanie wzrosła o $45 \%{ }^{47}$. Jeśli chodzi o strukturę konsumpcji gazu ziemnego, to w przypadku gospodarstw domowych nastąpił

45 BP Statistical Review of World Energy [online], 2021 [dostęp: 25 VIII 2021]: $<$ https://www.bp.com/en/global/corporate/energy-economics/statistical-review-of-world-energy/downloads.html $>$.

46 BP Statistical Review of World Energy...

47 In-depth review of the energy efficiency policy of the Republic of Azerbaijan..., s. 57. 
spadek o $8 \%$, natomiast w ramach sektora rolnictwa i usług konsumpcja tego surowca wzrosła odpowiednio dwu- i trzykrotnie ${ }^{48}$.

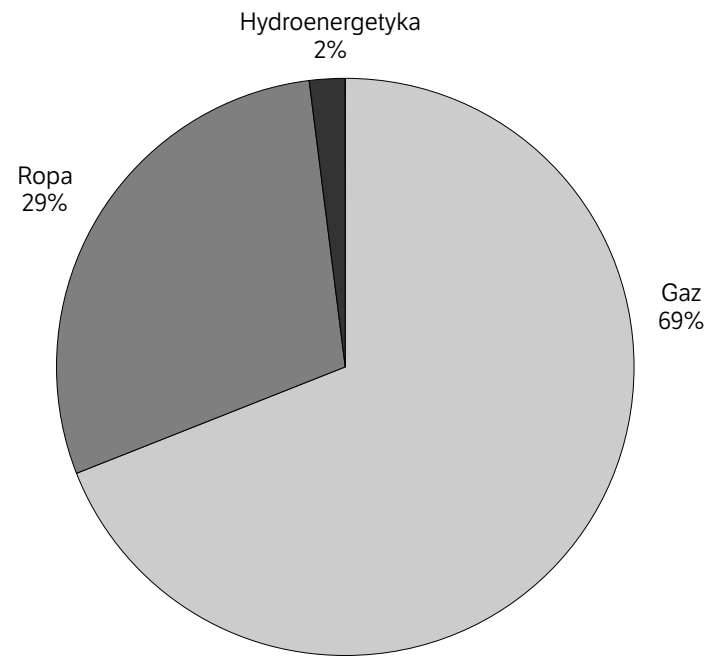

Diagram 1. Konsumpcja energii w Azerbejdżanie (2020)

Żródło:IEA 2021:https://www.eia.gov/international/analysis/country//ZZE [dostęp:12 IX 2021].

Azerbejdżan jest położony nad Morzem Kaspijskim, gdzie znajdują się znaczące potencjalne rezerwy ropy i gazu ${ }^{49}$. Zasoby surowcowe tego państwa usytuowane w tym akwenie, zarówno te potwierdzone, jak i potencjalne, mogą przyczynić się do dywersyfikacji zaspokojenia i stabilizacji dostaw w skali międzynarodowej ${ }^{50}$. Jednocześnie eksploatacja surowców zamkniętego zbiornika wodnego, jakim jest basen kaspijski, stanowi ogromne wyzwanie $\mathrm{z}$ uwagi na potrzebę budowania rozbudowanej infrastruktury rurociągowej. Produkcja węglowodorów w Azerbejdżanie jest skoncentrowana na polach Azəri-Çıraq-Günəşli (ACG) oraz Şahdəniz (mapa 1) ${ }^{51}$.

48 Tamże, s. 58.

49 Caspian Oil \& Gas, IEA: <http://www.iea.org/textbase/nppdf/free/199o/caspian_oil_ gas98.pdf> [dostęp: 12 IX 2013].

50 P. Ipek, Azerbaijan's Foreign Policy..., ss. 228-239.

51 G. Hall, T. Grant, Russia, China and the energy - security politics of the Caspian Sea region after the cold war, "Mediterranean Quarterly" 2009, issue 2, s. 66. 


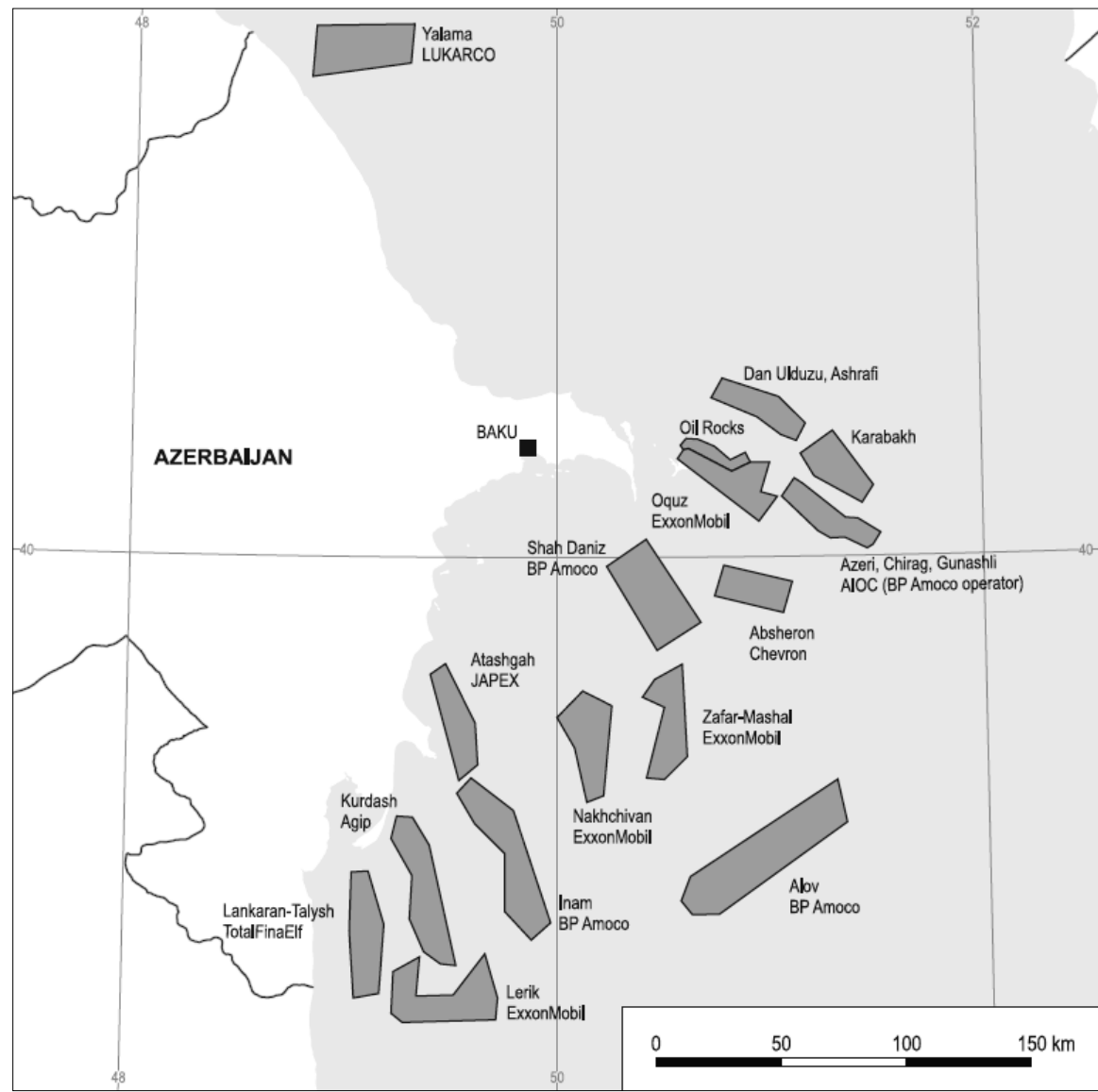

Mapa 1. Pola naftowe i gazowe w Azerbejdżanie

Źródło: J. Misiaggiewicz, Boundaries and energy security under dispute in the Caspian region, [w:] Border conflicts in the contemporary world, red. A. Moraczewska, W. Janicki, Wydawnictwo UMCS, Lublin 2014, s. 184.

Główne zasoby ropy w regionie znajdują się w obszarze Baku (Apszeron) oraz strefie Apszeron - Pribalkhash, gdzie znajduje się pole ACG. W roku 2020 przysporzyło ono aż $67 \%$ całkowitego dochodu Azerbejdżanu z handlu ropą naftową, czyli około 477 tys. baryłek dziennie ${ }^{52}$. Obecnie $75 \%$ ropy z regionu kaspijskiego Azerbejdżanu jest wydobywane właśnie z tych złóż. Pozostałe $25 \%$ pochodzi ze starych zasobów regionu Baku ${ }^{53}$.

52 IEA 2021: 〈https://www.eia.gov/international/analysis/country/AZE > [dostęp:12 IX 2021].

53 S. M. Senderov, Geopolitical features of energy security..., ss. 5-11. 
Większość zasobów gazu w Azerbejdżanie jest usytuowanych na polu Şahdəniz, gdzie rezerwy są szacowane na 1,2 tryliona $\mathrm{m}^{3}$ gazu. W pierwszej fazie rozbudowy tego obszaru produkcja rozpoczęła się pod koniec 2016 roku, a w drugiej - od 2018 roku. Głównym operatorem i udziałowcem tego pola gazowego jest BP. Wydobycie z tego rejonu stanowi $80 \%$ produkcji energii w Azerbejdżanie ${ }^{54}$. Zgodnie z prognozami druga faza rozbudowy tego pola może spowodować wzrost produkcji gazu do $24 \mathrm{mld} \mathrm{m}^{3}$ rocznie $^{55}$.

Oprócz głównych pól naftowych i gazowych funkcjonuje pięć perspektywicznych struktur wydobywczych gazu: Babek, Nakhchivan, Zafer Mashal, Araz - Alov - Sharg oraz Shafag - Asiman ${ }^{56}$. Nadprodukcja gazu, szacowana na $10 \mathrm{mld}^{3}$, spowodowała zwiększenie zainteresowania rynków zachodnich współpracą z Azerbejdżanem w wymiarze eksploatacji i eksportu tego surowca ${ }^{57}$.

\section{Zagrożenia bezpieczeństwa}

Konflikty, które narastały po odzyskaniu przez Azerbejdżan niepodległłości, wpłynęły w dużym stopniu na jego rozwój w wymiarze ekonomicznym oraz bezpieczeństwo narodowe. $\mathrm{W}$ ramach regionu kaspijskiego występowały dwa główne problemy wpływające na kształt polityki zagranicznej tego państwa. Po pierwsze, był to konflikt karabaski między Armenią i Azerbejdżanem, po drugie, nierozstrzygnięty status Morza Kaspijskiego.

Konflikt w Górskim Karabachu stanowił poważny i długotrwały problem w erze posowieckiej. W wyniku wojny Armenia okupowała około $12 \%$ terytorium Azerbejdżanu, co doprowadziło do uchodźstwa około miliona ludzi ${ }^{58}$. Azerbejdżan postrzegał konflikt karabaski jako zagrażający jego integralności terytorialnej i niepodległości. Zgodnie z Koncepcją Bezpieczeństwa Narodowego z 2007 roku „agresja przeciwko państwu stanowi główny determinant środowiska bezpieczeństwa i kluczowy czynnik

54 D. Stokes, S. Raphael, Global enerǵy security and American hegemony, Johns Hopkins University Press, Baltimore 2010, s. 116.

55 S. M. Senderov, Geopolitical ..., ss. 5-11.

56 M. Terterov, The energy charter..., ss. 213-230.

57 Tamże, ss. 213-230.

58 State Committee for Affairs of Refugees and Internally Displaced Persons of the Republic of Azerbaijan: 〈http://www.refugees-idps-committee.gov.az/en/> [dostęp: 21 VII 2017]. 
w procesie tworzenia Narodowej Polityki Bezpieczeństwa" ${ }^{\prime \prime 9}$. W myśl Doktryny Militarnej Azerbejdżanu z 2010 roku okupacja Górskiego Karabachu (GK) przez Armenię, poza kontrolą Azerbejdżanu, niszczy nie tylko bezpieczeństwo narodowe, ale również wpływa na bezpieczeństwo całego regionu ${ }^{60}$. Według prezydenta İlhamem Jliyevem brak rozwiązania konfliktu karabaskiego nie tylko wpłynął na środowisko bezpieczeństwa Azerbejdżanu i regionu kaspijskiego, ale stanowił także niebezpieczny precedens dla innych konfliktów, w różnych częściach świata ${ }^{61}$. Tym samym, zgodnie z deklaracją prezydenta, Azerbejdżan wykazuje idealistyczne dążenie do stworzenia takiego środowiska bezpieczeństwa, w którym państwa powstrzymują się od roszczeń terytorialnych wobec swoich sąsiadów. Ta zasada odnosi się również do działań aktorów zewnętrznych w regionie.

Konflikt karabaski stał się kwestią zasadniczą w tworzeniu priorytetów polityki zagranicznej i poszukiwaniu sojuszników wśród graczy regionalnych. Motywował również Azerbejdżan do prowadzenia aktywnej polityki eksportu surowców energetycznych. Dzięki zyskom z handlu ropą i gazem, państwo to mogło modernizować swoje siły zbrojne i tym samym wzmocnić swoją pozycję w konfrontacji z Armenią i ewentualnie Rosją ${ }^{62}$. Oprócz tego konsekwencją tego konfliktu był wzrost znaczenia Gruzji jako państwa tranzytowego dla surowców energetycznych eksportowanych przez Azerbejdżan na zachód Europy.

Porozumienie z 9 na 10 listopada 2020 roku jest sukcesem Azerbejdżanu, gdyż sankcjonuje prawnie przyłączenie większości terytorium GK i daje szansę na pełne przejęcie nad nim kontroli w przyszłości ${ }^{63}$. Wzmocni również pozycję prezydenta İ. Jliyeva, któremu udało się doprowadzić do zakończenia okupacji ziem Azerbejdżanu. Dzięki korytarzowi terytorialnemu do Nachiczewanu państwo to uzyska połączenie lądowe z Turcją ${ }^{64}$.

59 National Security Concept of the Republic of Azerbaijan, May 23, 2007: <http:// www.azembassy.org.au/uploads/docs/Azerbaijan.pdf $>$ [dostęp: 10 III 2014].

60 Republic of Azerbaycan [online], 2010 [dostęp: 26 IX 2015]: <http://www.mod.gov. az/doktrina.htm>.

61 I. Aliyev, Opening speech by at the Azerbaijan-USA Forum Future Vision, 29 V 2013 [dostęp: 28 IX 2015]: 〈http://president.az/mobile/articles/8311>.

62 P. Ipek, Azerbaijan's foreign policy ..., ss. 228-239.

63 A. Legieć, Rozejm w Górskim Karabachu, Polski Instytut Spraw Międzynarodowych, Warszawa 2020 (Komentarz PISM, 83).

64 Tamże. 
Spór dotyczący statusu Morza Kaspijskiego był kolejnym wyzwaniem dla polityki Azerbejdżanu ${ }^{65}$. Konflikt dotyczący podziału tego akwenu miał podstawowe znaczenie dla eksploatacji zasobów surowcowych u wybrzeży tego państwa ${ }^{66}$. W południowej części Morza Kaspijskiego Azerbejdżan, Iran i Turkmenistan wykazywały dużą aktywność w wymiarze militarnym w związku z nieporozumieniami dotyczącymi dostępu do złóż surowcowych (Kyapaz/Serdar, Azeri/Khazar, Chirag/Osman, Alborz/Alov). Azerbejdżan argumentował, iż akwen powinien być podzielony na sektory narodowe, w ramach których każde państwo przybrzeżne sprawowałoby wyłączną jurysdykcję. Prezydent Heydər Jliyev liczył, że dzięki gestom politycznym w postaci otwarcia się na inwestycje firm rosyjskich iż Rosja wesprze Azerbejdżan w sporze o dostęp do złóż basenu kaspijskiego i status prawny tego akwenu. Jednak, po podpisaniu kontraktów z korporacjami transnarodowymi, wystosowała ona ostrzeżenie, iż otwarcie Morza Kaspijskiego dla działań międzynarodowych w wymiarze eksploatacji złóż bez kontroli ze strony Rosji jest niedopuszczalne. Azerbejdżan przeprowadził szeroko zakrojone działania dyplomatyczne celem zagwarantowania sobie prawa do eksploatacji swojego sektora Morza Kaspijskiego ${ }^{67}$. Koncentrował się na podpisywaniu nowych kontraktów naftowych i budowie różnorodnej infrastruktury eksportowej $^{68}$. Mimo uregulowania podziału Morza Kaspijskiego na podstawie konwencji z 12 sierpnia 2018 roku nie ma ǵwarancji zakończenia sporów dotyczących jego eksploatacji. W przyszłości mogą pojawić się problemy, jeśli chodzi o interpretację konwencji, gdyż nie rozstrzyga ona jednoznacznie

65 Podczas Piątego Kaspijskiego Szczytu w Aktau w Kazachstanie, 12 sierpnia 2018 roku, Azerbejdżan, Iran, Kazachstan, Rosja i Turkmenistan podpisały konwencję regulującą status prawny Morza Kaspijskiego. Konwencja ustala ogólne reguły podziału basenu kaspijskiego, ale nie określa konkretnego podziału jego dna na sektory narodowe. Stwierdza jedynie, że „ich delimitacja odbędzie się na mocy porozumienia między państwami kaspijskimi z uwzğlędnieniem ogólnie uznanych zasad i norm prawa międzynarodowego": A. Legucka, Ureģulowanie statusu Morza Kaspijskiego, Polski Instytut Spraw Międzynarodowych, Warszawa 2018 (Biuletyn PISM, 116), ss. 1-3.

66 P. Ipek, Azerbaijan's foreign policy ..., ss. 228-239.

67 Tamże, ss. 228-239.

68 P. Ipek, Azerbaijan's foreign policy..., ss. 228-239; J. DeLay, Baku knows what's at stakeAliyev walks fine line on new oil deal, "Pipeline News" 1996, issue 42; J. DeLay, US delegation visits Baku for political, economic talks, "Pipeline News"1996, issue 38. 
morskiego statusu tego akwenu ${ }^{69}$. Oprócz tego Rosja będzie prawdopodobnie wzmacniać swoją obecność wojskową w akwenie kaspijskim ${ }^{70}$.

\section{Transformacja polityczna}

Kolejnym ważnym uwarunkowaniem polityki bezpieczeństwa energetycznego Azerbejdżanu jest sytuacja polityczna w tym państwie oraz rola liderów. Azerbejdżan ogłosił niepodległość 18 października 1991 roku $^{71}$. We wczesnych latach 90. sytuacja polityczna w tym państwie była niestabilna, co wiązało się z częstymi zmianami na stanowisku prezydenta ${ }^{72}$. Dopiero Heydər Jliyev pozostał na stanowisku aż dziesięć lat, od 24 czerwca 1993 roku do swojej śmierci w październiku 2003 roku $^{73}$. Obecny prezydent Azerbejdżanu, İlham Jliyev, sprawuje ten urząd od 31 października 2003 roku. Kontynuował on politykę ojca związaną z nawiązywaniem umów w ramach sektora energetycznego oraz przyciąganiem inwestorów zagranicznych. Przemiany wewnętrzne pociągnęly za sobą transformację polityki zagranicznej, której głównym celem stało się zapewnienie dochodów niezbędnych do stabilnego funkcjonowania reżimu ${ }^{74}$. Mimo ogromnych zysków ze sprzedaży ropy naftowej Azerbejdżan nie dokonał jednak transformacji $\mathrm{w}$ kierunku gospodarki wolnorynkowej. Proces demokratyzacji postępował powoli z uwagi na opresyjność rządu w stosunku do społeczeństwa oraz powiązania rodzinne i korupcyjne $w$ kręgach władzy ${ }^{75}$.

Azerbejdżan wykazuje cechy tzw. państwa-rentiera ${ }^{76}$. Po pierwsze, jest to państwo bogate w surowce energetyczne. Po drugie, dochody z eksportu

69 A. Legucka, Uregulowanie statusu Morza Kaspijskiego...

70 Podczas operacji militarnej w Syrii z okrętów Flotylli Kaspijskiej w cele na terytorium syryjskim wystrzeliwano rakiety manewrujące dalekiego zasięgu Kalibr (pokonywały odległość 1200-1500 km): A. Legucka, Uregulowanie statusu Morza Kaspijskiego...

71 R. Finn, Diplomatic beginning in Baku, [w:] Azerbaijan in global politics. Crafting foreign policy, eds A. Petersen, F. Ismailzade, Azerbaijan Diplomatic Academy, Baku 2009, s. 100.

72 E. Svyatets, Energy securit ..., ss. 74-109.

73 Tamże, ss. 74-109.

74 Por:: V. Babak, D. Vaisman, A. Wasserman, Political organization in Central Asia and Azerbaijan. Sources and documents, Routledge, London 2005.

75 P. Ipek, Azerbaijan: Oil boom and challenges, [w:] Turkey's neighborhood, ed. M. Kibaroglu, Foreign Policy Institute, Ankara 2008, ss. 129-131.

76 H. Beblawi, The rentier state in the Arab World, [w:] The Arab State, ed. G. Luciani, Routledge, Berkeley 1990, ss. 86-88. 
surowców stanowią znaczącą część jego PKB oraz całkowitego eksportu. Po trzecie, utrzymuje silną pozycję $\mathrm{w}$ procesie wytwarzania i dystrybucji dochodów $\mathrm{z}$ handlu ropą i gazem ${ }^{77}$. Państwa-rentierzy wykorzystują tym samym dochody z sektora energetycznego, by ograniczać przejawy demokratyzacji i zapobiegać działalności opozycji. Analizując sytuację w Azerbejdżanie, „w obliczu braku niezależnego sądownictwa i służby cywilnej, ministrowie, mając na uwadze własne interesy związane z preferencjami finansowymi i dostępem do kontraktów, są całkowicie uzależnieni od rodziny prezydenta i jej stronników" ${ }^{\prime 78}$. Nawet porozumienia z korporacjami zachodnimi są obciążone zjawiskiem korupcji. Dochody generowane w ramach tych kontraktów stanowią źródło bogactwa elit rządzących ${ }^{79}$. Oprócz tego państwa rentierskie stosują mechanizmy kontroli przestrzeni, w której mogłaby się pojawić opozycja, wydając dużo środków na zbrojenia i rozwój sił bezpieczeństwa. Azerbejdżan przeznacza około 4,6\% PKB na ten cel $^{80}$. Według M. Rossa przyczyną takiego zjawiska jest po pierwsze, dążenie do utrzymania reżimu, a po drugie, ochrona zasobów i infrastruktury energetycznej ulokowanej w regionach niestabilnych ${ }^{81}$.

\section{Działania Azerbejdżanu w wymiarze polityki bezpieczeństwa energetycznego $w$ regionie kaspijskim}

\section{Kontrakty z korporacjami transnarodowymi}

Kolejne umowy międzynarodowe dotyczące eksploatacji złóż surowcowych stanowiły odzwierciedlenie interesów strategicznych Azerbejdżanu oraz ich realizację. Sytuacja rozwijała się dynamicznie, gdyż już w 1992 roku podpisano dwa kontrakty z BP-Statoil i Pennzoil-Ramco, dotyczące eksploatacji

77 A. Almaz, Testing the rentier state theory. The case of Azerbaijan, "Journal of Global Analysis" 2015, vol. 5, issue 1-2, ss. 60-72.

78 R. Auty, Natural resources, governance and transition in energy rich Azerbaijan, Kazakhstan and Turkmenistan, Routledge, Abingdon 2004, s. 109; L. D. Shaw, Good governance in the post-Soviet South. Testing theories of the resource curse in Azerbaijan, "Journal of Politics and International Studies" 2013, vol. 9, ss. 534-535.

79 L. D. Shaw, Good governance..., s. 536.

80 CIA, World Fact Book 2020 [dostęp: 12 IX 2020]: 〈https://www.cia.gov/library/ publications/the-world-factbook/geos/aj.html>.

81 M. L. Ross, The oil course. How petroleum wealth shapes development of nations, Princeton University Press, Princeton 2012, s. 335. 
złóż ACG. Polityczną konsekwencją tego posunięcia był prozachodni kurs polityki zagranicznej Azerbejdżanu oraz pogorszenie relacji z Rosją, która została wykluczona z tych kontraktów naftowych.

W 1994 roku konsorcjum składające się z przedsiębiorstw zachodnich podpisało z rządem Azerbejdżanu tzw. transakcję stulecia ${ }^{82}$. Porozumienie to uwzględniało eksport ropy na rynki zachodnie. Celem tego przedsięwzięcia było zwiększenie bezpieczeństwa energetycznego państw Europy Zachodniej, jak również niezależności ekonomicznej regionu kaspijskiego. W ten sposób Azerbejdżan stał się strategicznym partnerem dla państw zachodnich. Może również odgrywać rolę państwa tranzytowego dla surowców energetycznych z Azji Centralnej ${ }^{83}$. „Kontrakt stulecia” wywarł zasadniczy wpływ na rozwój przemysłu naftowego i gazowego w Azerbejdżanie poprzez znaczące inwestycje, wprowadzanie nowoczesnych technologii $\mathrm{w}$ procesie eksploracji pól $\mathrm{w}$ obszarze morskim, modernizację infrastruktury naftowej i gazowej, zwiększenie produkcji ropy oraz umocnienie pozycji lidera na rynku. Oprócz tego zapoczątkowano eksport gazu i ropy do państw sąsiednich i do Europy, wdrażano projekty budowy dróg eksportu, inwestowano w badania i rozwój w sektorze ropy i gazu oraz stworzono Narodowy Fundusz Ropy gromadzący dochód z handlu tym surow$\mathrm{cem}^{84}$. Umowa ta była więc odzwierciedleniem strategii bezpieczeństwa energetycznego Azerbejdżanu.

W latach 1994-2008 podpisano 26 porozumień dotyczących zarządzania i eksploatacji azerbejdżańskich pól naftowych, w których uczestniczyło 41 korporacji z 19 państw. W konsekwencji Azerbejdżan stał się jednym z najbardziej znaczących producentów w regionie. Głównym operatorem rezerw energetycznych oraz infrastruktury przesyłowej $\mathrm{w}$ tym państwie została korporacja BP. W 2017 roku podpisano nowe porozumienia w Baku, stanowiące rozwinięcie „kontraktu stulecia”. Dotyczyły one rozwoju złóż

82 Uczestnikami umowy było trzynaście największych światowych korporacji (Amoco, BP, McDermott, Unocal, SocAR, LUKoil, Statoil, Exxon, Turkiye Petrolleri, Pennzoil, Itochu, Ramco, Delta) z ośmiu państw (Azerbejdżanu, USA, Wielkiej Brytanii, Rosji, Turcji, Norwegii, Japonii i Arabii Saudyjskiej): A. Cohen, Energy security in the Caspian basin, [w:] Energy security challenges..., s. 115.

83 Zob.: V. Socor, Gas discussions in Turkmenistan, Azerbaijan after the Budapest Nabucco Conference, „Eurasia Daily Monitor” 2007, vol. 4, issue 176.

84 K. Kosowska, R. Czarnota, J. Stopa, P. Wojnarowski, D. Janiga, Azerbaijan facing ..., ss. $267-274$. 
ACG do 2049 roku. Partycypowały w nich BP (30,37\% udziału), SOCAR $(25 \%)$, Chevron (9,57\%, INPEX (31\%), Equinor (7,27\%), Exxon Mobil $(6,7 \%)^{85}$.

19 września 2013 roku międzynarodowe konsorcjum eksploatujące azerskie złoże Şahdəniz podpisało kontrakty na dostawy $10 \mathrm{mld}^{3}$ gazu rocznie $\mathrm{z}$ drugiej fazy eksploatacji tego złoża ${ }^{86}$. Kontrakty zawarto na 25 lat z dziewięcioma europejskimi spółkami: Axpo, Bulgargaz, DEPA, Enel, E.oN, Gas Natural Aprovisionamientos, GDF Suez, Hera oraz Shell ${ }^{87}$. Nie wszystkie firmy ujawniły ilość zakontraktowanego gazu. Z oświadczenia azerbejdżańskiego państwowego koncernu socAR (który odgrywa najważniejszą rolę w konsorcjum) wynikało, że 8 mld $\mathrm{m}^{3}$ gazu miało trafić do Włoch (i stąd do Europy Zachodniej), $1 \mathrm{mld}^{3}$ do Grecji oraz $1 \mathrm{mld}^{3}$ do Bułgarii ${ }^{88}$.

Na przestrzeni ostatnich dziesięciu lat znacznie wzmocniła się pozycja Azerbejdżanu zarówno wobec poszczególnych konsorcjów, jak i samej UE ${ }^{89}$. Zwiększyły się także dochody Baku z eksportu ropy ${ }^{90}$.

\section{Główne projekty infrastruktury przesyłowej}

W okresie po odzyskaniu niepodległości Azerbejdżan stał się państwem atrakcyjnym dla rynku zachodniego z uwagi na potencjał energetyczny i pozycję geoekonomiczną ${ }^{91}$. Wzrost produkcji węglowodorów w Azerbejdżanie, jak również zwiększone zapotrzebowanie na światowych rynkach, spowodowało konieczność poszukiwań nowych dróg eksportu surowców ${ }^{92}$. Opcja budowy rurociągu Baku - Tbilisi - Ceyhan (BTC) była w tym kontekście optymalna

85 S. M. Senderov, Geopolitical features of energy security..., ss. 5-11.

86 A. Jarosiewicz, Azerbejdżan dzieli gaz z Szah-Deniz II, Ośrodek Studiów Wschodnich, 25 IX 2013 (Analizy OSw) [dostęp: 26 IX 2013]: <https://www.osw.waw.pl/pl/publikacje/ analizy/2013-09-25/azerbejdzan-dzieli-gaz-z-szah-deniz-ii $\rangle$.

87 Tamże.

88 Tamże.

89 A. Jarosiewicz, Południowy Korytarz Gazowy Azerbejdżanu $i$ Turcji [online], Ośrodek Studiów Wschodnich 2012 (Komentarze OSW) [dostęp: 20 VII 2012]: <https://www.osw.waw.pl/pl/publikacje/komentarze-osw/2012-07-18/poludniowykorytarz-gazowy-azerbejdzanu-i-turcji $>$.

90 Tamże.

91 I. S. Zonn, Pipeline architecture of the Black Sea-Caspian Sea region, [w:] Oil and Gas Pipelines in the Black-Caspian Seas..., ss. 75-84.

92 S. Bolukbasi, The controversy over the Caspian Sea mineral resources: Conflicting perceptions, clashing interests, "Europe-Asia Studies" 1998, vol. 3, issue 50, ss. 397-414. 
(mapa 2 ${ }^{93}$. W listopadzie 1999 roku, na szczycie OBWE w Stambule, podpisano porozumienie dotyczące transportu ropy przez terytoria Azerbejdżanu, Gruzji i Turcji przez główny rurociąg eksportowy Baku - Tbilisi - Ceyhan"94. Oprócz państw bezpośrednio uczestniczących w przedsięwzięciu umowę podpisały również USA i Kazachstan.

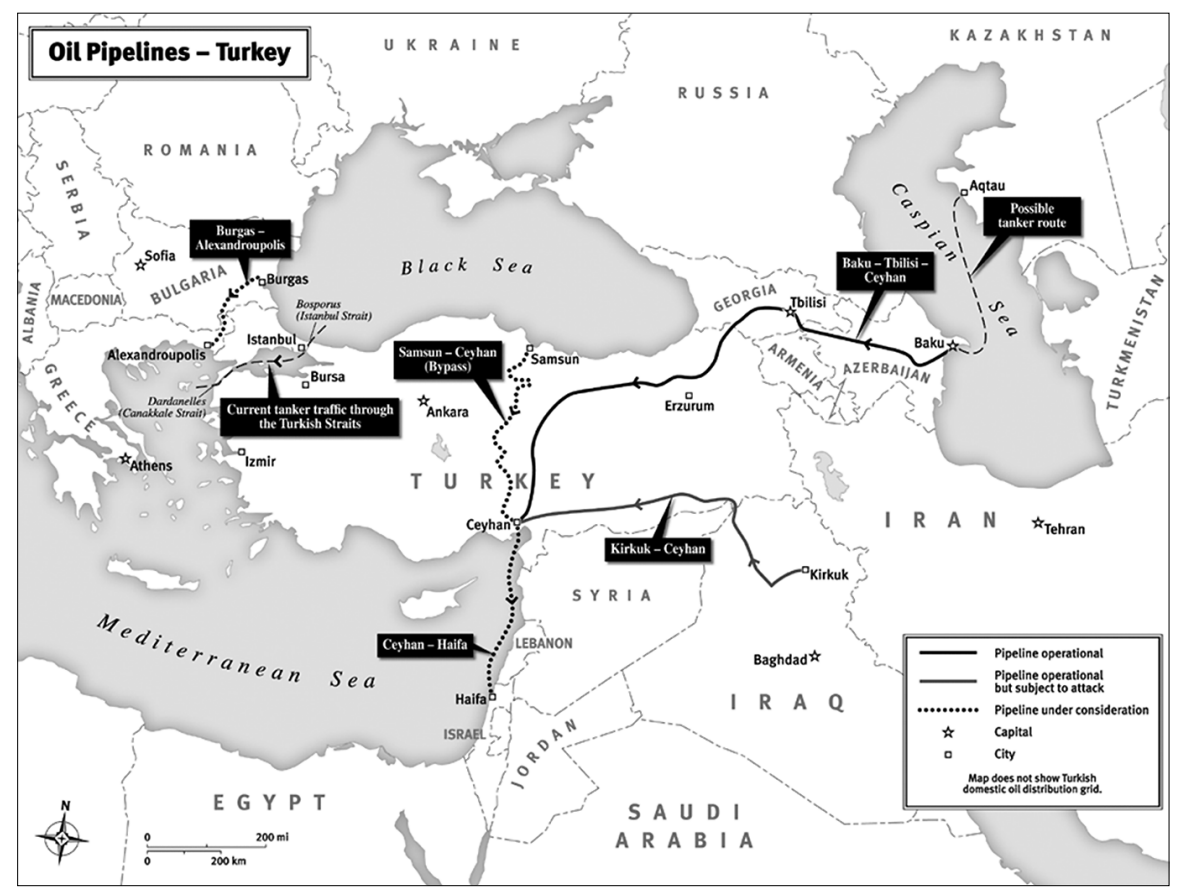

Mapa 2. Rurociąg BTC

Źródło: D. Fink, Assessing Turkey’s future as an energy transit country, "Research Notes" 2006, no 11, s. 3.

Była to najdroższa i najbardziej technologicznie rozbudowana infrastruktura przesyłowa w regionie. Rurociąg nie tylko jest długi, ale również wznosi się ponad 2 tys. metrów nad poziom morza, co powoduje konieczność zwiększenia liczby stacji pompujących. Jego długość wynosi $1750 \mathrm{~km}$, z czego $442 \mathrm{~km}$ przebiega przez terytorium Azerbejdżanu, $248 \mathrm{~km}$ przez Gruzję, a $1060 \mathrm{~km}$ przez terytorium Turcji ${ }^{95}$. Dziennie, rurociąg może trans-

93 T.Carroll, The cutting edge of accumulation. Neoliberal risk mitigation, the BakuTbilisi-Ceyhan pipeline and its impact, "Antipode" 2012, vol. 44, issue 2, ss. 281-302.

94 R. Huseynzade, A. Aliyev, Experience of Azerbaijan..., ss. 169-196.

95 Tamże, ss. 169-196. 
portować milion baryłek ropy. Na potrzeby obsługi rurociągu wybudowano ogromne terminale w Səngəçal w Azerbejdżanie i w Ceyhanie w Turcji. 25 maja 2005 roku po oficjalnej inauguracji ropa po raz pierwszy popłynęła z terminalu Səngəçal ${ }^{96}$.

Kryzys w stosunkach Rosji i Unii Europejskiej w związku z konfliktem na wschodzie Ukrainy sprawił, że kolejny mega projekt energetyczny Południowy Korytarz Gazowy stał się bliski realizacji ${ }^{97}$. UE upatrywała w nim szansę na rzeczywistą dywersyfikację dostaw gazu i sposób na wzmocnienie pozycji wobec Rosji ${ }^{9}$. Podpisanie decyzji w sprawie inwestycji w projekt Şahdəniz 2 odbyło się w Baku 23 grudnia 2013 roku. Konsorcjum Şahdəniz podjęło decyzję o powstaniu Gazociągu Transanatolijskiego (TANAP) przez terytorium Turcji oraz Gazociągu Transadriatyckiego (TAP) do Europy. Droga ta została nazwana Południowym Korytarzem Gazowym (mapa 3). Ceremonia inauguracji budowy Południowego Korytarza Gazowego odbyła się 20 września 2014 roku, a gazociąg okrzyknięto „projektem XXI wieku" ${ }^{\text {"99 }}$. Południowy Korytarz Gazowy to obecnie kontrolowany przez Azerbejdżan i Turcję system trzech uzupełniających się projektów gazociągów (Transkaukaskiego, Transanatolijskiego i Transdriatyckiego). Według Natural Gas Europe ogólny koszt budowy Południowego Korytarza Gazowego ma wynieść około 40 mld dolarów ${ }^{100}$. Większość wydatków została przeznaczona na rozwój infrastruktury wydobywczej Şahdəniz 2, rozbudowę Terminala Səngəçal u wybrzeży kaspijskich Azerbejdżanu, trzy projekty rurociągów, system odbioru gazu we Włoszech oraz możliwości połączeń z regionami południowej, środkowej i zachodniej Europy ${ }^{101}$. Z wyjątkiem TAP-u Azerbejdżan ma przeważającą większość udziałów w infrastrukturze gazociągów i będzie prawdopodobnie sprawować nad nią kontrolę.

96 Tamże, ss. 169-196.

97 V. Yorucu, M. Özay, The Southern Energy Corridor: Turkey's role in European energy security, Springer, Cham, Switzerland 2018.

98 Zob: J. Misiągiewicz, The Southern Gas Corridor infrastructure project - implications for the energy security of the European Union, „Rocznik Instytutu Europy ŚrodkowoWschodniej" 2019, t. 17, nr 4.

99 R. Huseynzade, A. Aliyev, Experience of Azerbaijan..., ss. 169-196.

100 M. Perzyński, TANAP oficjalnie otwarty w Baku, Biznes Alert, 28 v 2018 [dostęp: 12 XII 2018]: <http://biznesalert.pl/poludniowy-korytarz-gazowy-oficjalnieotwarty-w-baku>.

101 The Southern Gas Corridor, Trans Adriatic Pipeline [dostęp: 12 I 2019]: <https:// www.tap-ag.com/the-pipeline/the-big-picture/southern-gas-corridor >. 
Obecnie jedynym pewnym dostawcą gazu do Korytarza Południowego jest Azerbejdżan, który przeznaczył surowiec pochodzący z drugiej fazy zagospodarowania złoża Şahdəniz ${ }^{102}$. Dostępne ilości gazu to $16 \mathrm{mld} \mathrm{m}^{3}$ gazu rocznie ${ }^{103}$. Ponadto planuje on wydobycie ze złóż Umid oraz Babek, na których prace prowadzi SOCAR ${ }^{104}$. Dostawy z pozostałych potencjalnych źródeł gazu do Południowego Korytarza są problematyczne. Nie ma możliwości dostaw z Iraku, Egiptu oraz Iranu przede wszystkim ze wzğlędu na niestabilność sytuacji na Bliskim Wschodzie oraz z Turkmenistanu i Kazachstanu ze względu na brak infrastruktury niezbędnej do eksportu surowca przez Morze Kaspijskie ${ }^{105}$. Uruchomiona obecnie infrastruktura pozwala na eksport niewielkich ilości azerbejdżańskiego gazu $\left(10 \mathrm{mld}^{3}\right)$ na rynek europejski i w tym kontekście realizowałaby tylko część założeń unijnej koncepcji Południowego Korytarza Gazowego ${ }^{106}$.

Należy jednak zwrócić uwagę, iż nieodzownym warunkiem przyszłej efektywności Południowego Korytarza Gazowego jest perspektywa realizacji projektu Gazociągu Transkaspijskiego (mapa 4) przez Morze Kaspijskie do Azerbejdżanu i dalej na rynek europejski. Gazociąg mógłby przebiegać po dnie basenu kaspijskiego i łączyć stację przeładunkową w Turkmenbaszy z terminalem Sənģəçal w pobliżu Baku ${ }^{107}$. Planowana przepustowość infrastruktury to $30 \mathrm{mld}^{3}$ gazu rocznie ${ }^{108}$. Jednak, jak na razie, rurociąg nie może powstać z uwaği na spór między Azerbejdżanem i Turkmenistanem dotyczący jurysdykcji nad obszarem, na którym znajduje się złoże naftowe Kapaz/Serdar oraz złoża Azeri/Omar i Cirag/Osman ${ }^{109}$. Problemem jest

102 Tamże.

103 A. Jarosiewicz, Południowy Korytarz Gazowy...

104 Tamże.

105 Tamże.

106 A. Jarosiewicz, Start zmodyfikowanego Południowego Korytarza Gazowego, Ośrodek Studiów Wschodnich 2014 (Analizy Osw) [dostęp: 26 IX 2014]: <https://www.osw. waw.pl/pl/publikacje/analizy/2014-09-24/start-zmodyfikowanego-poludniowegokorytarza-gazowego $>$.

107 T. Sikorski, Perspektywy realizacji gazociagu trans kaspijskiego, Polski Instytut Spraw Międzynarodowych 2011 (Biuletyn PISM, 50).

108 Tamże.

109 Tamże; Zob.: J. Misiągiewicz, Boundaries and energy security under dispute in the Caspian region, [w:] Border conflicts in the contemporary World, red. A. Moraczewska, W. Janicki, Wydawnictwo UMCS, Lublin 2014. 


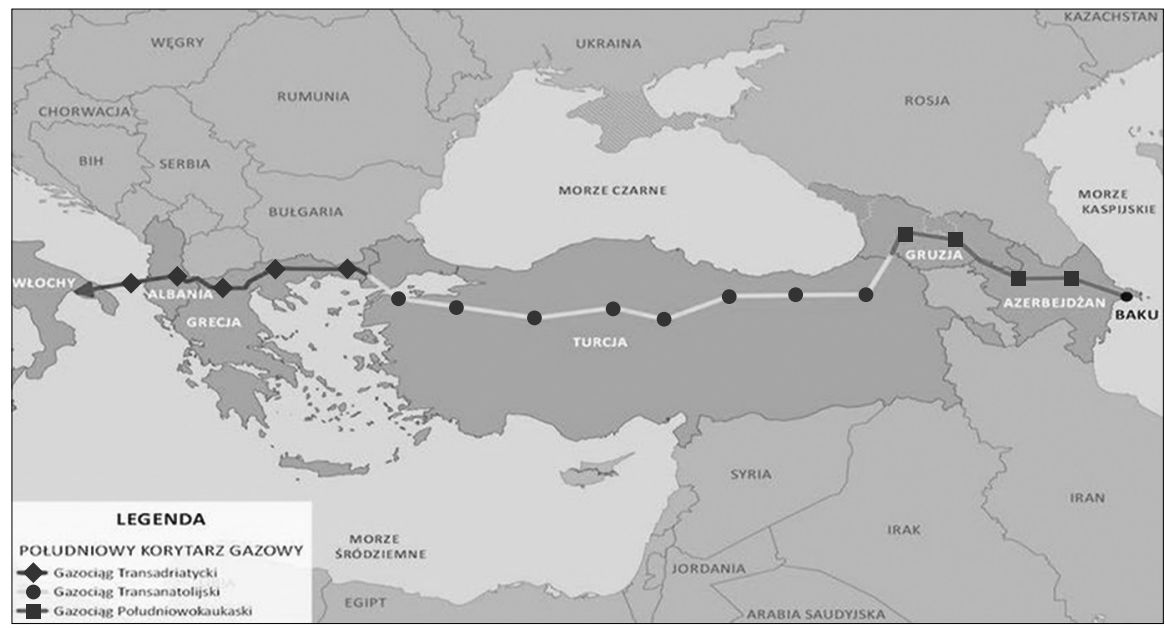

\section{Mapa 3. Południowy Korytarz Gazowy}

Źródło: Alijew: Południowy Korytarz Gazowy będzie gotowy za 2-3 lata, Energetyka 24, 28 VI 2018 [dostęp:12 III 2020]: <https://www. energetyka24.com/alijew-poludniowy-korytarz-gazowy-bedzie-gotowy-za-2-3-lata> [dostęp:12 III 2020].

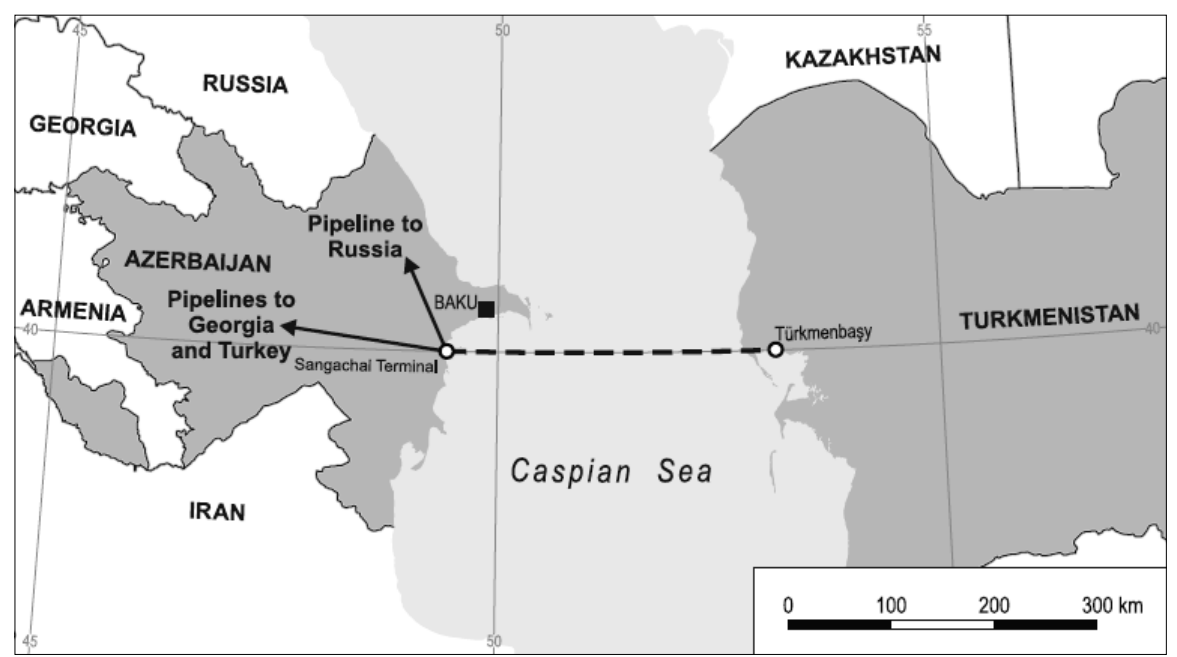

Mapa 4. Rurociąg Transkaspijski

Źródło: J. Misiagiewicz, Boundaries and energy security under dispute in the Caspian region, [w:] Border conflicts in the contemporary world, red. A. Moraczewska, W. Janicki, Wydawnictwo UMCS, Lublin 2014, s. 184.

również fakt, iż po 2009 roku większość gazu z Turkmenistanu jest eksportowana do Chin. 


\section{Uwagi końcowe}

Określone powyżej kwestie stanowiły przesłankę rozwiązania problemu badawczego i odpowiedź na główne pytanie badawcze: w jaki sposób i w wyniku jakich uwarunkowań dochodzi do ewolucji polityki bezpieczeństwa energetycznego Azerbejdżanu w regionie kaspijskim? Powyższa analiza umożliwiła również pozytywne zweryfikowanie hipotezy badawczej mówiącej, iż specyfika polityki bezpieczeństwa energetycznego Azerbejdżanu jest warunkowana jego pozycją geopolityczną, potencjałem surowcowym oraz ewolucją środowiska bezpieczeństwa w regionie kaspijskim.

Udowodniono bowiem, iż państwo to odgrywa coraz bardziej znaczącą rolę w stosunkach międzynarodowych, a zmieniające się okoliczności geopolityczne stworzyły nowe wyzwania dla jego polityki bezpieczeństwa energetycznego. Znaczenie Azerbejdżanu wzrosło w wyniku jego aktywności na rynku energetycznym ${ }^{110}$. Polityka bezpieczeństwa energetycznego Azerbejdżanu warunkowana jest wieloma problemami sektora energetycznego, takimi jak: geologiczna struktura nowo odkrytych i eksploatowanych pól, braki w wymiarze know-how, potrzeba przyciągania kapitału zagranicznego i inwestycji niezbędnych do eksploatacji surowców oraz kwestia efektywnych dostaw na rynek światowy ${ }^{111}$. Sukces Azerbejdżanu w wymiarze w surowcowym stał się paradoksalnie zagrożeniem, od kiedy państwo to uzależniło się od eksportu ropy i gazu ${ }^{112}$. Taki model rozwoju niesie za sobą duże ryzyko tzw. choroby holenderskiej, czyli podatności na negatywne zjawiska zewnętrzne. Dominujący sektor energetyczny warunkuje rozwój państwa, co powoduje spadek konkurencyjności i znaczenia innych branż w gospodarce. W rezultacie obniżka ceny surowców energetycznych może wpłynąć na drastyczny spadek dochodu państwa, a w rezultacie - poważny kryzys ${ }^{113}$.

110 S. Blank, Azerbaijan's expanding strategic perspective, "Central Asia-Caucasus Analyst" 2014, 5 March, ss. 7-10.

111 K. Kosowska, R. Czarnota, J. Stopa, P. Wojnarowski, D. Janiga, Azerbaijan facing..., ss. 267-274.

112 Country partnership strategy: Azerbaijan 2014-2018, Asian Development Bank, 2014: <http://www.adb.org/sites/default/files/institutional-document/81989/cps-aze-20142018-o.pdf> [dostęp: 10 XII 2015]; K. Kosowska, R. Czarnota, J. Stopa, P. Wojnarowski, D. Janiga, Azerbaijan facing..., ss. 267-274.

113 M. Terterov, The energy charter..., ss. 213-230. 
Egzegeza polityki bezpieczeństwa energetycznego Azerbejdżanu $\mathrm{w}$ regionie kaspijskim stanowiła duże wyzwanie badawcze. Jest to bowiem kwestia bardzo dynamiczna w kontekście licznych niewiadomych związanych z funkcjonowaniem międzynarodowego rynku energetycznego.

\section{Bibliografia}

Alijew: Poludniowy Korytarz Gazowy będzie gotowy za 2-3 lata, Energetyka 24, 28 VI 2018 [dostęp: 12 III 2020]: <https://www.energetyka24.com/alijewpoludniowy-korytarz-gazowy-bedzie-gotowy-za-2-3-lata $\rangle$

Aliyev I., Opening speech by at the Azerbaijan-USA Forum Future Vision, 29 V 2013 [dostęp: 28 IX 2015]: 〈http://president.az/mobile/articles/8311〉.

Aliyev I., Azeri leader sets key priorities for 2007, “BBC Monitoring Trans Caucasus Unit",1 I 2007.

Almaz A., Testing the rentier state theory. The case of Azerbaijan, "Journal of Global Analysis" 2015, vol. 5, issue 1-2.

Auty R., Natural resources, governance and transition in Azerbaijan, Kazakhstan, Routledge, Abingdon 2004.

Azerbaijan, IEA, 13 I 2021 [dostęp:12 IX 2021]:<https://www.eia.gov/international/ analysis/country/AZE $>$.

Babak V., Vaisman D., Wasserman A., Political organization in Central Asia and Azerbaijan. Sources and dDocuments, Routledge, London 2005.

Bagirov S., Azerbaijan's strategic choice in the Caspian Region, [w:] The security of the Caspian Sea Region, ed. G. Chufrin, Oxford University Press, London 2001.

Bahgat G., Central Asia and enerǵy security, "Asian Affairs” 2006, vol. 37, issue 1, s. 3.

Bahgat G., Energy security. The Caspian Sea, "Minerals \& Energy" 2005, vol. 20, issue 2.

Beblawi H., The rentier state in the Arab world, [w:] The Arab state, ed. G. Luciani, Routledge, Berkeley 1990.

Blank S., Azerbaijan's expanding strategic perspective, "Central Asia-Caucasus Analyst" 5 III 2014.

Bolukbasi S., The controversy over the Caspian Sea mineral resources: Conflicting perceptions, clashing interests, "Europe-Asia Studies" 1998, vol. 3, issue 50.

BP Statistical Review of World Energy, 2021 [dostęp: 25 VIII 2021]: <https://www. bp.com/en/global/corporate/energy-economics/statistical-review-of-world-energy/downloads.html>.

Brzeziński Z., Wielka szachownica, Politeja, Warszawa 1999.

Carroll T., The Cutting edge of accumulation. Neoliberal risk mitigation, the BakuTbilisi-Ceyhan pipeline and its impact, "Antipode" 2012, vol. 44, issue 2.

Caspian oil \& gas, IEA : <http://www.iea.org/textbase/nppdf/free/199o/caspian_oil_ gas98.pdf $>$ [dostęp: 12 IX 2013]. 
CIA World Fact Book 2020, [dostęp: 12 IX 2020]: <https://www.cia.gov/library/ publications/the-world-factbook/geos/aj.html >.

Cohen A., Energy security in the Caspian basin, [w:] Energy security challenges for 21st century, ed. G. Luft, A. Korin, Greenwood Publishing Group, Santa Barbara 2009.

Country partnership strategy: Azerbaijan 2014-2018, Asian Development Bank, 2014: http://www.adb.org/sites/default/files/institutional-document/81989/cps-aze-2014-2018-o.pdf> [dostęp: 10 XII 2015].

Dalby S., American security discourse: the persistence of geopolitics, "Political Geography Quarterly" 1990, issue 9(2).

DeLay J., Baku knows what's at stake - Aliyev walks fine line on new oil deal, "Pipeline News" 1996, issue 42.

DeLay J., US delegation visits Baku for political, economic Talks, "Pipeline News"1996, issue 38.

Fink D., Assessing Turkey's future as an energy transit country, "Research Notes" 2006, issue 11.

Finn R., Diplomatic beginning in Baku, [w:] Azerbaijan in global politics: Crafting foreign policy, ed. A. Petersen, F. Ismailzade, Azerbaijan Diplomatic Academy, Baku 2009.

van Gils E., Azerbaijan and the European Union, Routledge, New York 2020.

Goble P., Azerbaijan's balanced foreign policy and the muslim world, "Azerbaijan in the World" 2009, issue 2(12).

Goldberg J., Getting crude in Baku. The crude face of global capitalism, "The New York Times Magazine" [online], 4 X 1998 [dostęp: 12 V 2019]: <https://www. nytimes.com/1998/10/04/magazine/the-crude-face-of-global-capitalism.html $>$.

Hall G., Grant T., Russia, China and the energy - security politics of the Caspian Sea Region after the cold war, "Mediterranean Quarterly" 2009, issue 2.

Huseynzade R., Aliyev A., Experience of Azerbaijan in construction of main oil and gas pipelines in the Caspian Sea Region. Environmental aspects, [w:] Oil and gas pipelines in the Black-Caspian Seas Region, eds I. S. Zonn, A. G. Kostianoy, Springer, Switzerland 2016.

Ilham Aliyev: Energy security cannot be considered apart from national security, AEA Albania Energy Asociation, 18 XI 2015 [dostęp: 12 IX 2021]: <https://aea-al. org/ilham-aliyev-energy-security-cannot-be-considered-apart-from-national-security/>.

Index Mundi, [dostęp: 25 VIII 2020]: <https://www.indexmundi.com/g/g. aspx? $\mathrm{v}=136 \& \mathrm{c}=\mathrm{aj} \& \mathrm{l}=\mathrm{en}>$.

In-depth review of the energy efficiency policy of the Republic of Azerbaijan, Energy Charter Protocol on Energy Efficiency and Related Environmental Aspects, PEEREA, 2019 : <https://www.energycharter.org/what-we-do/energy-efficiency/ energy-efficiency-country-reviews/in-depth-review-of-energy-efficiency-policies-and-programmes/in-depth-review-of-the-energy-efficiency-policy-of-the-republic-of-azerbaijan/> [dostęp: 12 IX 2021]. 
Ipek P., Azerbaijan: oil boom and challenges, [w:] Turkey's neighborhood, ed. M. Kibaroglu, Foreign Policy Institute, Ankara 2008.

Ipek P., Azerbaijan's foreign policy and challenges for energy security, "Middle East Journal" 2009, vol. 63, issue 2.

Jafarova E., The role of Azerbaijan in shaping regional cooperation for energy security, [w:] Addressing emerging security risks for energy networks in South Caucasus, eds J. Novogrockiene, E. Siaulyte, IOS Press, Amsterdam 2017.

Jarosiewicz A., Azerbejdżan dzieli gaz z Szah-Deniz II, Ośrodek Studiów Wschodnich 2013 (Analizy OSw) [dostęp: 26 IX 2013]: <https://www.osw.waw.pl/pl/publikacje/ analizy/2013-09-25/azerbejdzan-dzieli-gaz-z-szah-deniz-ii $>$.

Jarosiewicz A., Południowy Korytarz Gazowy Azerbejdżanu $i$ Turcji, Ośrodek Studiów Wschodnich 2012 (Komentarze OSW) [dostęp: 20 VII 2012]: <https:// www.osw.waw.pl/pl/publikacje/komentarze-osw/2012-07-18/poludniowy-korytarz-gazowy-azerbejdzanu-i-turcji $>$.

Jarosiewicz A., Południowy Korytarz Gazowy Azersko-turecki projekt w rozgrywce Rosji i UE, Ośrodek Studiów Wschodnich 2015 (Punkt Widzenia, 54).

Jarosiewicz A., Start zmodyfikowanego Południowego Korytarza Gazowego, Ośrodek Studiów Wschodnich 2014 (Analizy OSW) [dostęp: 26 IX 2014]: <https:// www.osw.waw.pl/pl/publikacje/analizy/2014-09-24/start-zmodyfikowanegopoludniowego-korytarza-gazowego $>$.

Joint press point with NATO Secretary General Anders Fogh Rasmussen and the President of Azerbaijan, Ilham Heydar oglu Aliyev,15 I 2014 [dostęp: 27 IX 2015]: <http:// www.nato.int/cps/en/natolive/opinions_106145.htm?selectedLocale=en $\rangle$.

Kolundzić S., Eurasia, enerǵy cooperation or conflict?, Part 2. Caspian Region, oil and geopolitics, "NAFTA" 2009, vol. 4, issue 60.

Kosowska K., Czarnota R., Stopa J., Wojnarowski P., Janiga D., Azerbaijan facing new challenges on the energy market after the collapse of Soviet Union, [w:] Section oil and gas exploration, 18 International Multidisciplinary Scientific GeoConference SGEM 2018.

Kublik A., Kaspijski gaz u granic Europy. Nadchodzi konkurencja dla Gazpromu, 13 vI 2018 [dostęp: 12 V 2018]: <http://wyborcza.pl/7,155287,23531503,kaspijski-gaz-u-granic-europy-nadchodzi-konkurencja-dla-gazpromu.html $>$.

Legieć A., Perspektywy polityki wewnętrznej i zagranicznej Azerbejdżanu, Polski Instytut Spraw Międzynarodowych, Warszawa 2020 (Biuletyn PISM, 87).

Legieć A., Rozejm w Górskim Karabachu, Polski Instytut Spraw Międzynarodowych, Warszawa 2020 (Komentarz PISM, 83).

Legucka A., Uregulowanie statusu Morza Kaspijskiego, Polski Instytut Spraw Międzynarodowych, Warszawa 2018 (Biuletyn PISM, 116).

Mammadov F., Azerbaijan's geopolitical identity in the context of the 21st century challenges and prospects, Valdai Discussion Club, 2017 (Valdai Papers, 62): <http:// valdaiclub.com/files/13184/> [dostęp: 15 VI 2017]. 
Mammadov F., Foreign policy postures and priorities of Azerbaijan, [w:] The South Caucasus - security, energy and Europeanization, ed. M. B. Altunisik, O. F. Tanrisever, Routledge, London, New York 2018.

Misiagiewicz J., Boundaries and energy security under dispute in the Caspian region, [w:] Border conflicts in the contemporary world, red. A. Moraczewska, W. Janicki, Wydawnictwo UMCS, Lublin 2014.

Misiaggiewicz J., The Caspian states perception of the conflict between the Ukraine and Russia, [w:] Neighbourhood perceptions of the Ukraine crisis, eds K. Stokłosa, G. Besier, Routledge, London - New York 2017.

Misiagiewicz J., The Southern Gas Corridor infrastructure project - implications for the energy security of the European Union, „Rocznik Instytutu Europy ŚrodkowoWschodniej" 2019, t. 17, nr 4.

National security concept of the Republic of Azerbaijan [online], 23 V 2007 [dostęp: 10 III 2014]: 〈http://www.azembassy.org.au/uploads/docs/Azerbaijan.pdf $\rangle.$

NATO in the Caucasus. The case of Azerbaijan, 2014 [dostęp: 19 IX 2015]: 〈http://www. isn.ethz.ch/DigitalLibrary/Audio/Detail/?lng=en\&id=183160 >.

Opening speech by Ilham Aliev of the Cabinet of Ministers, [dostęp: 12 VIII 2020]: $\langle$ http://ru.president.az/articles/29539>.

Perzyński M.,TANAPoficjalnieotwartyw Baku, Biznes Alert, 28V 2018 [dostęp:12 XII 2018] $\langle$ http://biznesalert.pl/poludniowy-korytarz-gazowy-oficjalnie-otwarty-w-baku $\rangle$.

Pop V., EU too divided to solve frozen conflicts, Azerbaijan says, "EU Observer" [online], 9 X 2008 [dostęp:15 X 2015]: 〈https://euobserver.com/energy/26894〉.

Republic of Azerbaijan, Ministry of Foreign Affairs, [dostęp:12 III 2014]: <http:// dmfa.nakhchivan.az/page.php?lang $=$ eng\&page $=030049>$.

Republic of Azerbaijan, National Security Concept of the Republic of Azerbaijan, 2007, ss. 8-9, : 〈http://www.azembassy.org.au/uploads/docs/Azerbaijan.pdf〉 [dostęp: 29 X 2015].

Republic of Azerbaycan, 2010 [dostęp: 26 IX 2015]: <http://www.mod.gov.az/doktrina.htm>.

Ross M.L., The oil course. How petroleum wealth shapes development of nations, Princeton University Press, Princeton 2012.

Shaw L. D., Good governance in the post-Soviet South. Testing theories of the resource curse in Azerbaijan, "Journal of Politics and International Studies" 2013, vol. 9.

Sikorski T., Perspektywy realizacji gazociagu trans kaspijskiego, Polski Instytut Spraw Międzynarodowych 2011 (Biuletyn PISM, 50).

Socor V., Gas discussions in Turkmenistan, Azerbaijan after the Budapest Nabucco Conference, „Eurasia Daily Monitor” 2007, vol. 4, issue 176.

The Southern Gas Corridor, Trans Adriatic Pipeline, [dostęp: 12 I 2019]: <https:// www.tap-ag.com/the-pipeline/the-big-picture/southern-gas-corridor $\rangle$.

State Committee for Affairs of Refugees and Internally Displaced Persons of the Republic of Azerbaijan: <http://www.refugees-idps-committee.gov.az/ en/> [dostęp: 21 VII 2017]. 
Stokes D., Raphael S., Global energy security and American hegemony, Johns Hopkins University Press, Baltimore 2010.

Strakes J., Azerbaijan and the non-aligned movement. Institutionalizing the 'Balanced Foreign Policy' Doctrine, "IAI Working Papers", 11 V 2015.

Svyatets E., Energy security and cooperation in Eurasia. Power, profits and politics, Routledge, New York 2016.

Terterov M., The energy charter as a framework for intergovernmental cooperation in the energy markets of the South Caucasus states, [w:] The South Caucasus - security, energy and europeanization, eds M. B. Altunisik, O. F. Tanrisever, Routledge, London - New York 2018.

US Energy Information Administration, [dostęp: 10 II 2015]: <http://www.eia.gov/ beta/international/?fips $=a j>$.

Yergin, D. The quest. Energy, security, and the remaking of the modern world, Penguin Books, New York, 2011.

Yorucu V., Özay M., The Southern Energy Corridor. Turkey's role in European energy security, Springer, Cham, Switzerland 2018.

Zonn I. S., Pipeline architecture of the Black Sea-Caspian Sea Region, [w:] Oil and gas pipelines in the Black-Caspian Seas Region, eds I. S. Zonn, A. G. Kostianoy, Springer, Switzerland 2016. 